\title{
LEARNING OUTCOMES FOR LIFELONG LEARNING IN THE CONTEXT OF LATVIAN VOCATIONAL SECONDARY EDUCATION
}

\author{
Gunta Kinta \\ University of Latvia
}

\begin{abstract}
Using learning outcomes, which are defined as statements of what a learner knows, understands and is able to do after learning, may support lifelong learning, since the outcome of education rather that input and process are emphasised. In Latvia vocational education is considered to have important role in the context of lifelong learning. Therefore, this study aimed at exploring views of vocational education students concerning the role of lifelong learning knowledge, skills and competences in vocational secondary education. The questionnaire including 19 statements of general learning outcomes was completed by 1817 vocational education students from 25 vocational schools. The results of the study indicate that the respondents appreciate the importance of these learning outcomes, although in case of some statements the respondents do not have clear understanding how these learning outcomes relate to their occupation.
\end{abstract}

Keywords.Learning outcomes, key competences, vocational secondary education.

\section{Introduction}

Both in Latvia and in other European countries the introduction or support to learning outcomes based education may be seen as a tool for promoting participation in lifelong learning. For an instance, learning outcomes are emphasised in the process of setting up national qualifications frameworks and referencing them to the European Qualifications Framework (EQF) for lifelong learning. Since learning outcomes - statements of what a learner knows, understands and is able to do after some period of learning (European Parliament and the Council, 2008) - focus on the actual achievements of learners instead of how these results were gained, this approach is more suitable in the context of lifelong learning when individuals with various previous experiences and expectations seek for their further development.

Vocational education system based on learning outcomes in Latvia has a potential for facilitating lifelong learning, which has been indicated in several policy planning documents, e.g. Guidelines for lifelong learning policy for 2007-2013 (2007), and concept Raising attractiveness of vocational education and involvement of social partners within vocational education quality assurance (2009). By differentiating vocational education offer both in terms of content and structure, the availability of vocational education for various social groups is expected to be promoted. Vocational education programmes already represent a large range of economic sectors, and it is crucial that the programmes ensure the acquisition of knowledge, skills and competences relevant to labour market needs. Yet taking into account the rapid development 
of technologies and changing requirements, each individual should master some basic, general and transferable knowledge, skills and competences to be applied in or adapted to unpredictable situations.

Therefore, a study was carried out with the aim to explore the meaning of lifelong learning knowledge, skills and competences in the Latvian vocational secondary education. Second year vocational education students were surveyed to support the aim of this study.

\section{The concept of learning outcomes}

Learning outcomes comprise knowledge, skills, competences, attitudes and values that students obtain during a certain period of learning and may apply in their further education and employment. Since learning outcomes should be measurable, i.e. teachers should be able to observe and students - demonstrate their achievements, usually learning outcomes describe only knowledge, skills, competences. In this paper knowledge is defined as a set of systemised cognitive units forming in the course of various situations. Skills comprise ability to perform cognitive and physical operations, which usually are obtained through learning or work. Competence is explained as ability to demonstrate how a person is able to apply their knowledge and skills independently in various unpredictable situations (Vocational Education Administration, 2007). These three dimensions are used in the context of the European Qualifications Framework; thus, it has been an agreement among international experts.

The most significant features of learning outcomes are as follows:

- Learning outcomes are measurable - expected outcomes should be formulated the way that teacher and students are able to assess the extent the learning outcomes have been mastered;

- Learning outcomes are attainable - students should be able to achieve the expected outcomes in the particular period of time;

- Learning outcomes are determined in advance - both teacher and students are aware of expected outcomes before certain learning activity has been commenced;

- Learning outcomes show progress of an individual student - when assessing student's performance, all participants may observe how student's knowledge, skills and competences have improved comparing to the beginning of learning period;

- Learning outcomes are understandable for all the stakeholders - individuals involved in education process are informed about and understand the meaning of expected outcomes;

- Obtained learning outcomes are confirmed by demonstrating - students should be able to show in relevant manner the outcomes they have mastered (Battersby, 1999; Melton, 1997; Moon, 2002). 
One of the issues when formulating learning outcomes is to decide, which set of learning outcomes should be included in particular course or education programme. Since the variety of education programmes is evident is increasing, some major requirements for expected learning outcomes should be drawn. An example of such agreement at international level were eight general learning outcomes, which were outlined by the Recommendation of the European Parliament and of the Council on key competences for lifelong learning (December 2006) and which should be to some extent be mastered by all inhabitants. In the recommendation the term "key competences" is understood as a holistic concept imparting knowledge and skills. Yet in this study learning outcomes are considered to be the overarching concept that consists of knowledge, skills and competences. The eight key competences or general learning outcomes are communication in the mother tongue; communication in foreign languages; mathematical competence and basic competences in science and technology; digital competence; learning to learn; social and civic competences; sense of initiative and entrepreneurship; and cultural awareness and expression (European Parliament and the Council, 2006).

In terms of an OECD programme, Rychen and Hersh Salganik (2001) summarised the views of several experts concerning general learning outcomes and concluded that three main categories of key competences may be distinguished:

- Acting autonomously - an individual is aware of their rights and interests, is able to initiate interaction with environment and develop strategies for achieving their goals;

- Using tools interactively - an individual possesses relevant tool and is able to use it properly, as well as is aware of ways how the tool influences their interaction with environment;

- Interacting in heterogeneous groups - an individual is able to perceive and comprehend opinion of others, solve conflicts of interests by working in group, and is willing to form common strategies (Rychen, Hersh Salganik, 2001).

The key competences usually are described as multifunctional and multidimensional, transferable from one field to other, and related to a higher stage of mental development (Rychen, Hersh Salganik, 2001). Hence, general learning outcomes do not refer to a certain field or discipline of study; they are generic to be applied in various economic sectors and life situations.

\section{The Methodology of Study}

This study was carried out in vocational secondary education, which in Latvia is ensured after nine-year basic education or general secondary education. Vocational secondary education programmes are four-years long and lead to a 
diploma of vocational secondary education and the Latvian professional qualification level 3, i.e. EQF level 4. The graduates obtain rights to enrol in higher education. The secondary education level also includes three-year long vocational education programmes, which, according to the Vocational Education Law (1999), are part of vocational secondary education programmes and lead to the Latvian professional qualification level 2, i.e. EQF level 4. The graduates do not have right to enrol directly in higher education programmes, but a one-year long intermediate general education course is available for those willing to continue at a higher education institution.

The general aim of the vocational education students' poll was exploring respondents' opinion concerning education process; knowledge, skills and competences necessary for professionals; and students' assessment. Regarding the focus of this paper, only some of the questions included in the questionnaire are outlined and analysed here.

The respondents were asked to evaluate in four-point Likert scale 19 statements describing general learning outcomes, which they considered to be or not important for a good professional. Thereafter, the respondents had to name, which of these examples were the most significant in their future occupation. These statements of learning outcomes were formulated on basis of general learning outcomes included in the Recommendation of the European Parliament and of the Council on key competences for lifelong learning (December 2006), the OECD programme (Rychen, Hersh Salganik, 2001), a vocational secondary education programme, as well as using the descriptions of the Latvian Qualifications Framework levels included in the Cabinet of Ministers Regulations on the classification of Latvian education (2008, 2010). Thus, these 19 sentences were general and did not refer to a specific field or qualification.

Prior the collection of data, the questionnaire was piloted; 83 respondents, who were randomly selected vocational education students of both sexes, completed pilot questionnaire. Thereafter, the questionnaire was revised and improved accordingly.

In total, the questionnaire was completed by 1838 vocational education students (in data analysis 1817 questionnaires were included) from 25 vocational education establishments located in different regions of Latvia. Data were collected in two periods: from November to December in 2010 (577 respondents) and from October to December 2012 (1260 respondents). The second survey was conducted in order to gain more thorough information about the research questions.

The sample for the poll was made by applying two-stage sampling procedures: stratified and random. First, in each of five regions of Latvia at least two large and two small schools in terms of the number of students were selected. The large education establishments were or were expected to become a vocational education competence centre, i.e. a school with additional functions, for 
example, ensuring lifelong learning for various social groups (Ministry of Education and Science, 2009). As result, in total six schools were located in Riga and its region, four schools - Kurzeme, and five schools per region in Zemgale, Latgale and Vidzeme.

Second, at school level randomly $2^{\text {nd }}$ year students were selected for the survey. $2^{\text {nd }}$ year students were chosen because this study addresses the processes observed in schools. Usually most of the students obtain their practical learning in enterprises after their second year; meanwhile, these students have already formed stable opinion about their learning at school. Therefore, $2^{\text {nd }}$ year students seemed to be the most appropriate for this study.

The following distribution of respondents by region was observed in the study: Riga and its region - 485 students, Kurzeme - 384 students, Zemgale - 302 students, Latgale -300 students and Vidzeme - 346 students.

For the data processing and analysis, the SPSS programme was applied. Firstly, descriptive statistics methods, e.g. frequencies, percentage, were used to exclude potential data processing errors and gain overview of the collected data. Secondly, Pearson's correlation coefficient was calculated to determine potential connections between two variables. To avoid asymmetry in results and taking into account the disproportional distribution of the respondents by region, when calculating correlations, data were weighted by region.

\section{Main Results and Discussion}

The valid questionnaires were completed by 800 females and 1017 males. The age of respondents varied from 14 to 29 years; the greatest part of respondents was 17 years old $(65.7 \%)$ and 18 years old $(18 \%)$.

The students from 54 various vocational education programmes participated in the survey. The greatest part of respondents represented hotel and restaurant sector (25.8\%); operations with real estate, rental and other businesses (19.1\%); wholesale and retail trade, repair of motor vehicles, motorcycles, household goods and equipment (16.7\%); and manufacturing industry sector (12.8\%).

Regarding the evaluation of 19 statements of learning outcomes, which respondents considered to be significant for a good professional, the replies were mainly positive $-97.2 \%$ to $73.8 \%$ of respondents noted "yes" or "rather yes than no". In order to summarize the results, the data collected in four-point Likert scale were grouped in absolute positive (yes, rather yes than no) and negative (rather no than yes, no) answers.

The most important examples of learning outcomes (97.2-95.2\% of the respondents replied positive) were ability to take responsibility; work independently; learn and acquire new technologies; realize their ideas; and use relevant working methods and tools. Comparatively less significant statements (89.8-73.8\% of the respondents replied positive) referred to the ability to solve 
conflicts; communicate in foreign languages; be familiar with surrounding environment and people; manage work of others; use their understanding of math, science and technology; and have grasp of culture. According to the respondents, good specialists are responsible, independent, innovative and quick learners, who do not need to posses efficient communicative skills, or use mathematics and natural sciences, or understanding of culture in their work. This aspect indicates that the students do not consider these general learning outcomes useful, despite the fact that the mentioned hard sciences have been set as political priorities both at national and international level. Moreover, the calculation of Pearson's correlation coefficient did not support any correlation between the respondents' future qualification and 19 statements of learning outcomes, i.e. regardless the profile of their vocational education programme the students did not consider the foresaid learning outcomes particularly important. When comparing replies collected in 2010 and 2012, slightly more respondents in the second survey answered negative; thus, in the first survey more statements were considered to be evidently important (about 10 examples of learning outcomes $98.1-95.1 \%$ of respondents replied positive). The results collected during the both rounds of survey are summarised in Table 1 .

When arranging the statements of learning outcomes by their priority, some learning outcomes obtained less importance in the second survey round in 2012 - ability to learn and acquire new technologies; use various cognitive and practical skills; work in team; take initiative, as well as knowing facts and theories about occupation. Meanwhile, the significance of some other learning outcomes increased in 2012 - ability to work independently; realize their ideas; use relevant working methods and tools; communicate in the state language; find creative solutions; plan and organize their activity; and use information technologies.

These changes in priorities comprise some contradictions - good specialists should be able to work independently, put their creative ideas in practice with the help of relevant tools including information technologies and methods. Yet their ability to acquire innovative technologies, show initiative and possess knowledge of their field, which would help in performing the important learning outcomes, is not relevant.

According to the calculations of Pearson's correlation coefficient, no significant correlations between the examples of learning outcomes were determined neither when all data were analysed, nor separate rounds of survey in 2010 and 2012. 
Table 1

The most important learning outcomes of a good specialist, 2010 and 2012 (\%)

\begin{tabular}{|l|c|c|c|c|c|c|}
\hline & \multicolumn{2}{|l|}{ Absolute positive } & \multicolumn{2}{l|}{ Absolute negative } & \multicolumn{2}{c|}{ No reply } \\
\hline & 2010 & 2012 & 2010 & 2012 & 2010 & 2012 \\
\hline Work independently & 95.8 & 96.0 & 3.9 & 4.0 & 0.4 & 0.0 \\
\hline Take responsibility & 98.1 & 96.8 & 1.8 & 3.1 & 0.2 & 0.1 \\
\hline $\begin{array}{l}\text { Familiarity with environment and } \\
\text { people }\end{array}$ & 83.9 & 83.7 & 15.4 & 15.3 & 0.7 & 1.0 \\
\hline Work in team & 95.8 & 92.9 & 3.4 & 6.8 & 0.9 & 0.3 \\
\hline $\begin{array}{l}\text { Use relevant working methods and } \\
\text { tools }\end{array}$ & 95.8 & 95.0 & 3.2 & 4.4 & 1.1 & 0.6 \\
\hline Solve conflicts & 92.0 & 88.7 & 7.2 & 11.0 & 0.7 & 0.3 \\
\hline Communicate in the state language & 95.1 & 93.4 & 4.6 & 6.6 & 0.4 & 0.0 \\
\hline Communicate in foreign languages & 89.4 & 87.2 & 10.4 & 12.2 & 0.2 & 0.6 \\
\hline $\begin{array}{l}\text { Use understanding of math, science } \\
\text { and technology }\end{array}$ & 78.8 & 75.0 & 21.0 & 24.7 & 0.2 & 0.3 \\
\hline Use information technologies & 93.1 & 92.9 & 6.0 & 6.5 & 0.9 & 0.6 \\
\hline Learn and acquire new technologies & 97.2 & 94.9 & 2.1 & 4.6 & 0.7 & 0.5 \\
\hline Take initiative & 95.4 & 92.6 & 4.1 & 7.2 & 0.5 & 0.2 \\
\hline Realize their ideas & 96.1 & 95.2 & 3.4 & 4.6 & 0.5 & 0.2 \\
\hline Grasp of culture & 75.3 & 73.1 & 24.2 & 26.8 & 0.5 & 0.1 \\
\hline Find creative solutions & 95.1 & 93.2 & 4.2 & 6.5 & 0.7 & 0.3 \\
\hline Know facts and theories & 93.8 & 91.5 & 4.9 & 7.8 & 1.2 & 0.6 \\
\hline Use thinking and practical skills & 96.8 & 93.3 & 3.2 & 6.4 & 0.0 & 0.3 \\
\hline Plan and organize their activity & 94.0 & 93.0 & 5.8 & 6.7 & 0.2 & 0.3 \\
\hline Manage work of others & 80.9 & 76.3 & 18.4 & 23.5 & 0.7 & 0.2 \\
\hline
\end{tabular}

In the next question, the respondents chose three learning outcomes of 19 examples, which were the most important in their future occupation. Regardless the order how three statements were named, the most important the respondents considered ability to work independently ( $13.8 \%$ of replies), take responsibility $(12.2 \%)$, work in team $(9.4 \%)$, communicate in foreign languages $(7.4 \%)$, learn and acquire new technologies (6.6\%), and realize their ideas (6.4\%). Quite few students selected the following learning outcomes: grasp of culture $(1 \%$ of replies); take initiative (2.2\%); manage work of others $(2.7 \%)$; use understanding of math, science and technology $(2.8 \%)$; as well as familiarity with surrounding environment and people $(2.9 \%)$. The results show that the respondents wish to obtain independence and assume responsibility in their work, as well as communication skills and ability to learn would help in becoming more efficient in their occupation. Although working in a team was noted as important, being familiar with the surrounding environment and other people, i.e. social relations, had less value. The other contradiction was 
emphasising independence and team work, but underestimating the meaning of initiative and management skills.

Table 2

Four the most and least important learning outcomes in future occupation, arranged by priority, in 2010 and 2012 (\%)

\begin{tabular}{|l|c|l|c|}
\hline \multicolumn{2}{|c|}{2010} & \multicolumn{2}{c|}{2012} \\
\hline Learning outcome & $\begin{array}{c}\text { \% of } \\
\text { replies }\end{array}$ & \multicolumn{1}{c|}{ Learning outcome } & $\begin{array}{c}\% \text { of } \\
\text { replies }\end{array}$ \\
\hline Take responsibility & 13.8 & Work independently & 13.8 \\
\hline Work independently & 13.8 & Take responsibility & 11.5 \\
\hline Work in team & 10.2 & Work in team & 9.1 \\
\hline Communicate in foreign languages & 7.6 & Communicate in foreign languages & 7.4 \\
\hline$\ldots$ & $\ldots$ & $\ldots$ & $\ldots$ \\
\hline Take initiative & 2.4 & Solve conflicts & 2.9 \\
\hline $\begin{array}{l}\text { Use understanding of math, science and } \\
\text { technology }\end{array}$ & 2.1 & Manage work of others & 2.6 \\
\hline Use information technologies & 2.0 & Take initiative & 2.1 \\
\hline Grasp of culture & 1.3 & Grasp of culture & 0.9 \\
\hline
\end{tabular}

The results of both rounds of survey (see Table 2) indicate that in 2012, ability to realize their ideas; find creative solutions; use information technologies; use various cognitive and practical skills; use understanding of math, science and technology; and knowing facts and theories about occupation had become more important in the respondents' future occupation. In the second round of survey less important learning outcomes than in the first round appeared to be ability to learn and acquire new technologies, plan and organize their activity, be familiar with environment and people, solve conflicts, manage work of others, and take initiative. Although some changes may be observed in the priority of selected learning outcomes both for data in total and separate rounds of survey, differences between rates are rather slight to have a thorough evidence for any tendencies. In Table 2 below only four the most important and four the least significant learning outcomes are shown due the limited volume of this paper. The replies concerning the learning outcomes important for good professionals and in future occupation were quite similar. For an instance, in both cases ability to take responsibility and work independently was the most significant. In addition, in both questions as less important learning outcomes, grasp of culture; use understanding of math, science and technology; and manage work of others were considered. Thus, the students considered that being independent and responsible employees, who are able to learn, is highly important, yet managing work of others was less significant. When applying learning outcomes in education, ensuring students' autonomy is essential because learners should be aware of their progress and plan their learning. To help students become more 
independent, learning situations should be arranged in a way to make students assume responsibility and make decisions. The fact that management skills are not relevant, according to the respondents, is contradictory. The description of the Latvian Qualifications Framework level 4 corresponding to vocational secondary education foresees that learners should be able to manage team work, which was named as less relevant. As mentioned before, the respondents' opinion differed from the views expressed in the policy planning documents concerning the hard sciences and culture. This opposition of students may be grounded in the fact that mainly these disciplines are mainly explored in general study subjects, although when relevant vocational education programmes may include them as vocational study subjects. The general study subjects seem to lack links with vocational study subjects. Of course, since general study subjects have to be implemented according to the state general education standards, but in a shorter period of time, and the number of classes is limited, introducing more topics relevant to students' future qualification is rather challenging. Therefore, major education content and structure reforms, which would involve the revision of the state education standards and vocational education programmes, should be conducted.

Still some differences between learning outcomes relevant to good specialists and the respondents' future occupation were also observed - for a good professional ability to use various cognitive and practical skills and take initiative were more important than in the respondents' future occupation. The ability to work in team, communicate in foreign languages, and knowing facts and theories about the field were considered to be more relevant for the future occupation than for good professionals in general. According to the results, communicative and interpersonal skills were more important in the respondents' future occupation, while taking initiative was more useful for good professionals in general. Good professionals should be able to use various skills, but the respondents should know various facts and theories about their future occupation. These discrepancies between learning outcomes for good professionals and the respondents' future occupation suggest that the students do not directly relate their learning with the actual professional activity yet. This is supported by the fact that no significant correlations were determined between learning outcomes important for a good professional and the respondents' future occupation.

\section{Conclusions}

The respondents in general recognized the importance of lifelong learning outcomes both for good professionals and their future occupation. As the most significant learning outcomes, clearly working independently and assuming responsibility were considered; thus, the students' autonomy in their learning 
should be promoted. The use of learning outcomes in vocational education can support learner's autonomy, because students need to take an active role and manage their own learning.

The understanding of culture and math, science and technology was estimated to have lesser meaning in professional life. The students mostly relate these topics with general study subjects, the use of which in their future career they doubt, or general study subjects fail to provide relevant occupational context. Thus, links between study subjects should be strengthened to ensure a holistic approach to the acquisition of qualification. In the rapidly changing labour market, these general learning outcomes are valuable in promoting the flexibility of graduates. The observed differences between learning outcomes more important for good professionals and respondents' future occupation indicate that the students do not completely see themselves as ready-made professionals, which is rather regular in the middle of education programme. Yet learning situations should be arranged in a way to relate present learning with future professional activity; and learning outcomes can assist in providing such links and context.

\section{Kopsavilkums}

Lietojot mācīšanās rezultātus profesionālajā vidējā izglīî̄îa, uzsvars tiek likts uz faktisko izglîtīibas iznākumu, nevis izglītîbas ilgumu vai veidu, kādā apgūtas konkrētās zināšanas, prasmes un kompetences. Šis aspekts ir būtisks mūžizglîtīibā, jo iesaistītajām personām ir atšķirīga pieredze un intereses. N̦emot vērā strauji main̄̄gās darba tirgus prasības, svarīgi, ka iedzīvotāji apgūst vispārīgus mācīšanās rezultātus, kurus iespējams izmantot dažādās darba un dzīves situācijās un kuri neattiecas uz noteiktu profesionālo jomu.

Šì pētījuma mērksis bija noskaidrot, kāda ir vispārīgo mācǐšanās rezultātu nozīme profesionālajā vidējā izglîtībā. Tāpēc tika aptaujāti 2. kursa profesionālās izglìtîbas audzēkṇi - pavisam datu analīzē tika iekl̦autas 1817 anketas, kuras aizpildīja audzēkṇi no 25 Latvijas profesionālās izglìtības iestādēm.

Aptaujas rezultāti liecina, ka pārsvarā respondenti anketā iekḷautos vispārīgos mācišanās rezultātus novērtēja kā nozīmīgus. Vissvarīgākie māciššnās rezultāti bija spēja darboties patstāvīgi un uzņemties atbildību, bet vismazāk svarīgie bija spēja orientēties kultūrā un izmantot izpratni par matemātiku, dabas zinātnēm un tehnologijāām.

\section{Acknowledgements}

This work has been supported by the European Social Fund within the project "Support for Doctoral Studies at University of Latvia".

\section{Bibliography}

1. Battersby, M. (1999). So, what's a learning outcome anyway? Center for Curriculum, Transfer and Technology. (ERIC Accession No. ED430611). 
2. Cabinet of Ministers $(1999,2010)$. Vocational education law. Latvijas Vēstnesis. Vol. 205, Issue 4397, 29.12.2010.

3. Cabinet of Ministers $(2000,2010)$. Regulations on the state vocational secondary education standard and the state vocational education standard. Latvijas Véstnesis. Vol. 144, Issue 4336, 10.09.2010.

4. Cabinet of Ministers $(2008,2010)$. Regulations on the classification of the Latvian education. Latvijas Vēstnesis. Vol. 160, Issue 4352, 08.10.2010.

5. European Parliament and Council (2006). Recommendation on key competences for lifelong learning. Official Journal of the European Union. Vol. L 394, Issue 10, 30.12.2006.

6. European Parliament and Council (2008). Recommendation on the establishment of the European Qualifications Framework for lifelong learning. Official Journal of the European Union. Vol. C 111, Issue 1, 6.5.2008.

7. Melton, Reginald F. (1997). Objectives, competencies and learning outcomes: Developing instructional materials in open and distance learning. Great Britain: Biddles Ltd, Guildford and King's Lynn.

8. Ministry of Education and Science (2009). Guidelines for lifelong learning policy for 2007-2013. Cabinet of Ministers: Riga.

9. Ministry of Education and Science (2009). Raising attractiveness of vocational education and involvement of social partners within vocational education quality assurance. Cabinet of Ministers: Riga.

10. Moon, J. (2002). The module and programme development handbook: A practical guide to linking levels, outcomes and assessment criteria. Great Britain: Kogan Page Limited.

11. Rychen, Dominique Simone \& Hersh Salganik, Laura (2001). Definition and selection of key competencies. A contribution of the OECD program definition and selection of competencies: theoretical and conceptual foundations. Retrieved 24.01.2010, from http://www.deseco.admin.ch/bfs/deseco/en/index/02.parsys.69356. downloadList.26477.DownloadFile.tmp/2000.desecocontrib.inesg.a.pdf.

12. Vocational Education Administration (2007). Methodology for development of occupational standards. In: ESF project Development of a Unified Methodology for the Quality Improvement of Vocational Education and Involvement and Education of Social Partners. Riga: Vocational Education Administration.

\begin{tabular}{|c|l|}
\hline Gunta Kinta & University of Latvia \\
& e-pasts: uguntina@gmail.com \\
& Tel.: +37126111843 \\
\hline
\end{tabular}

